\title{
IMPLEMENTASI PEMBERIAN BANTUAN HUKUM BAGI RAKYAT MISKIN DI JAWA TENGAH BERDASARKAN UNDANG-UNDANG NOMOR 16 TAHUN 2011 TENTANG BANTUAN HUKUM
}

\author{
Yusuf Saefudin \\ Fakultas Hukum Universitas Jenderal Soedirman \\ Email: yusufalasha@gmail.com
}

\begin{abstract}
The establishment of the act of no. 16 years old 2011 about legal aid give new hope to the poor to get access to justice (access to justice) and similarity in to law (equality before the law). This research intend to understand the extent of the implementation of the provision of assistance in central java and the obstacles affecting it in their implementation. The research is the qualitative study with the methods normatif-empiris approach. Data collection is done with the study documents and interviewing people who are considered closely connected with the problems the treatment. The accumulated data analyzed by using analysis of qualitative data. Act of no. 16 years old 2011 about legal aid not implementation well in central java. The factors that hinder there are three, people the substance legal factors, legal structure and cultural law.
\end{abstract}

Keyword: Legal Aid, Implementation of legal aid, Poor folk in Central Java, UUBH

\begin{abstract}
Abstrak
Lahirnya Undang-Undang No. 16 Tahun 2011 tentang Bantuan Hukum memberikan harapan baru bagi rakyat miskin untuk mendapatkan akses terhadap keadilan (access to justice) dan kesamaan dihadapan hukum (equality before the law). Penelitian ini bermaksud untuk mengetahui sejauh mana implementasi pemberian bantuan di Jawa Tengah serta hambatan-hambatan yang mempengaruhinya dalam implementasinya. Penelitian ini merupakan penelitian kualitatif dengan metode pendekatan normatifempiris. Data yang digunakan adalah data sekunder dan data primer. Pengumpulan data dilakukan dengan studi dokumen dan wawancara terhadap orang-orang yang dianggap berhubungan erat dengan permasalahan yang diteliti. Data yang terkumpul dianalisis dengan menggunakan analisis data kualitatif. UU No. 16 Tahun 2011 tentang Bantuan Hukum belum terimplementasi dengan baik di Jawa Tengah. Faktor-faktor yang menghambat ada tiga, yakni: faktor substansi hukum, struktur hukum dan budaya hukum.
\end{abstract}

Kata Kunci: Bantuan Hukum, Implementasi Bantuan Hukum, Rakyat Miskin Jawa Tengah, UUBH.

\section{Pendahuluan}

Hak atas Bantuan Hukum telah diterima secara universal yang dijamin dalam Kovenan Internasional tentang Hak-Hak Sipil dan Politik (International Covenant on Civil and Political Right (ICCPR)). Pasal 16 dan Pasal 26 ICCPR menjamin semua orang berhak memperoleh perlindungan hukum serta harus dihindarkan dari segala bentuk diskriminasi. Sedangkan Pasal 14 Ayat (3) ICCPR, memberikan syarat terkait bantuan hukum yaitu kepentingan-kepentingan keadilan dan tidak mampu membayar advokat.

Ketentuan Pasal 1 Ayat (3) Undang-Udang Dasar Negara Republik Indonesia Tahun 1945 (UUD NRI 1945) menegaskan bahwa Negara In- donesia adalah negara hukum. Dalam konteks negara hukum, negara mengakui dan melindungi hak asasi manusia bagi setiap individu termasuk hak atas bantuan hukum. Penyelenggaraan pemberian bantuan hukum kepada warga negara merupakan bentuk upaya untuk memenuhi sekaligus sebagai implementasi dari negara hukum yang mengakui dan melindungi serta menjamin hak asasi warga negara akan kebutuhan akses terhadap keadilan (acces to justice) dan kesamaan dihadapan hukum (equality before the law). Jaminan atas hak konstitusional tersebut belum mendapatkan perhatian secara memadai, sehingga dibentuknya Undang-Undang Nomor 16 Tahun 2011 tentang Bantuan Hukum (UUBH) 
menjadi dasar bagi negara untuk menjamin warga negara, khususnya bagi orang atau kelompok orang miskin untuk mendapatkan akses keadilan dan kesamaan dihadapan hukum.

Bambang Sunggono dan Aries Harianto mengemukakan jika selama ini si kaya sudah cukup merasakan keadilan dan si miskin sudah cukup terjauh dari keadilan, maka sudah saatnya keadaan yang demikian tidak terjadi lagi. Program bantuan hukum, khususnya bagi si miskin, pada dasarnya merupakan pemerataan keadilan. ${ }^{1}$ Frans Hendra Winarta berpendapat, "Sering kali orang yang tergolong miskin (the have not) diperlakukan tidak adil dan tidak dapat memperoleh jasa hukum dan pembelaan (access to legal councel) yang memadai dari advokat (penasihat hukum)". ${ }^{2}$
Berdasarkan pada data BPS tahun 2012, Provinsi Jawa Tengah menempati posisi kedua yang jumlah penduduk miskinnya paling banyak di Indonesia dengan angka 4,86 juta jiwa dengan prosentase kemiskinan $14,98 \%$. Data statistik tersebut membuktikan bahwa penuduk dalam katagori miskin di Indonesia masih cukup tinggi dan tentu saja kehadiran bantuan hukum terhadap mereka harus mendapatkan perhatian yang serius. Keadilan bagi orang yang mampu yang tidak mampu masih jauh tertinggal dibandingkan keadilan bagi yang mampu. Keadilan bagi yang tidak mampu hanya dapat dicapai melalui bantuan hukum. ${ }^{3}$ Data kemiskinan di atas dapat dilihat pada grafik berikut:

Grafik I: Persebaran kemiskinan di Indonesia berdasarkan provinsi

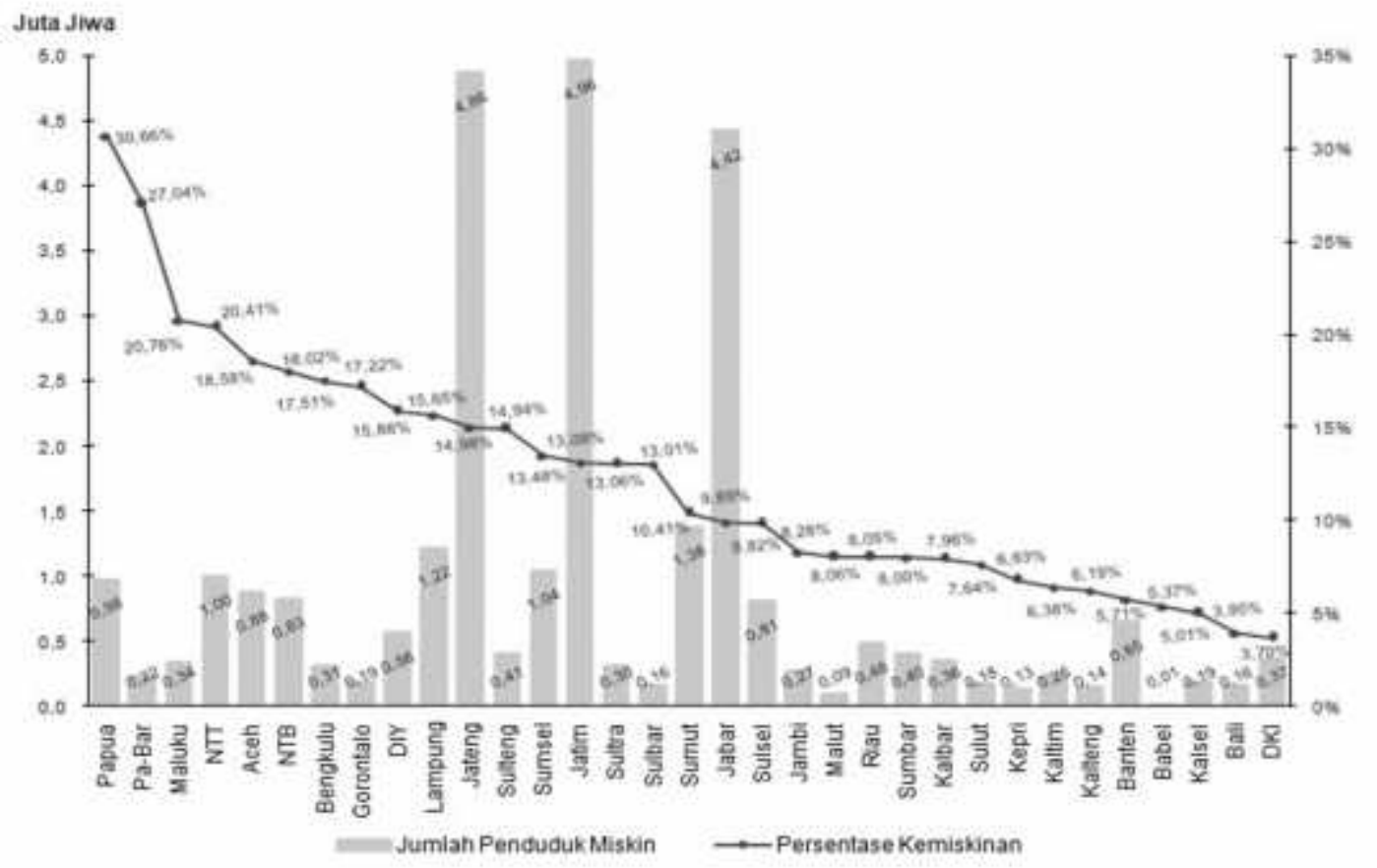

Sumber: Data BPS bulan September 2012 yang diolah

Bambang Sunggono dan Aries Harianto, 2009, Bantuan Hukum dan Hak Asasi Manusia, CV. Mandar Maju, Bandung, hlm. 62.

2 Frans Hendra Winarta, Bantuan Hukum; Suatu Hak Asasi Manusia Bukan Belas Kasihan, (Jakarta: PT Elex Media Komputindo Kelompok Gramedia, 2000), hlm. 50.
3 Frans Hendra Winarta, Probono Publico (Hak Konstitusional Fakir Miskin untuk Memperoleh Bantuan Hukum), (Jakarta: PT. Gramedia, 2009), hlm 165. 
Data diatas menjadi perhatian bahwa Provinsi Jawa Tengah rawan terhadap tindak kriminal, dimana salah satu faktor penyebab orang melakukan kejahatan karena faktor ekonomi. Tidak sedikit dari sekelompok orang miskin yang dimanfaatkan oleh para pengusasanya untuk mencapai tujuan tertentu. Keberadaan mereka perlu diperhatikan dan dilindungi, khususnya berkaitan dengan hukum. Adapun mengenai peta persebaran kemiskinan di Provinsi Jawa Tengah dapat dilihat pada gambar berikut:

Gambar I: Peta distribusi penduduk miskin di Provinsi Jawa Tengah

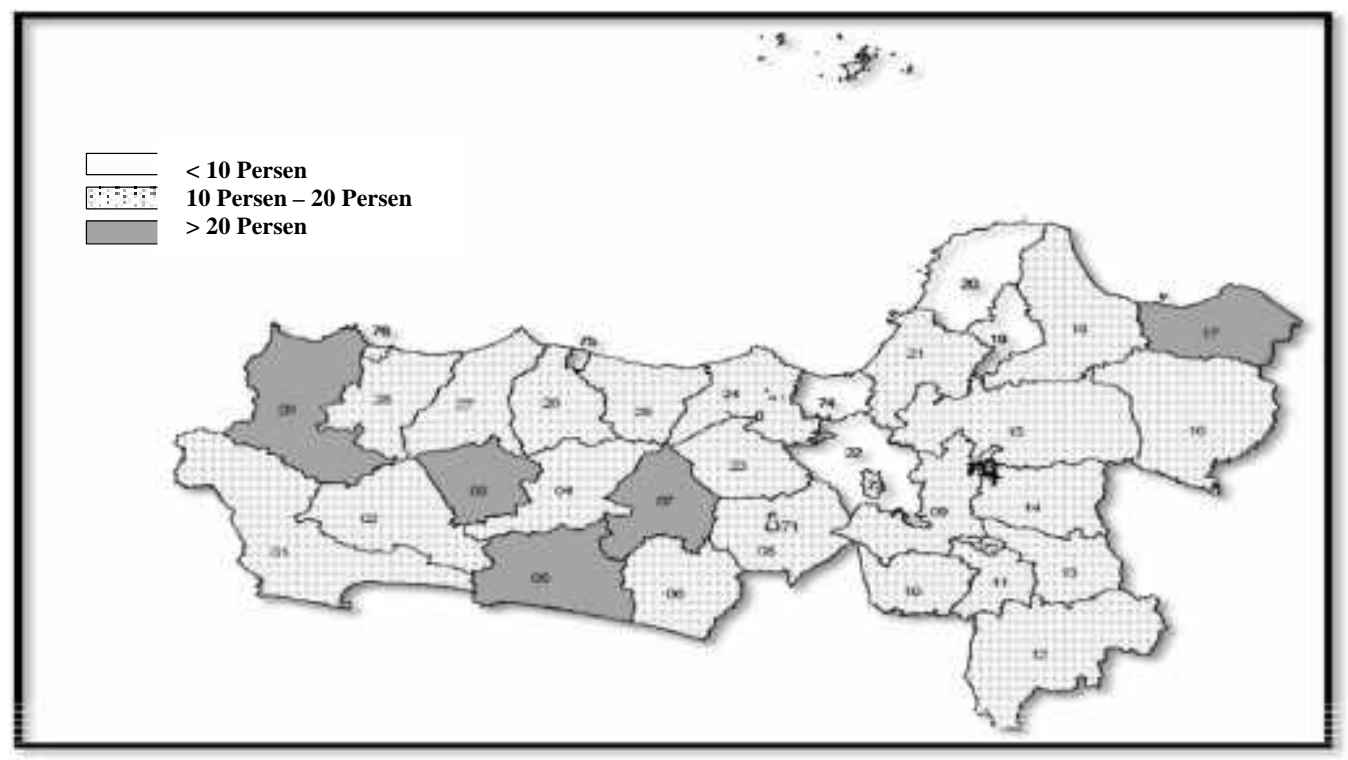

Sumber: BPS Jawa Tengah tahun 2012

Peserbaran kemiskinan di Jawa Tengah mayoritas berada diwilayah pedesaan, seperti di Kabupaten Wonosobo, Kabupaten Temanggung, Kabuaten Purbalingga dan Kabupaten Brebes. Di wilayah kabupaten tersebut, masih terdapat daerah yang jauh dari kota. Hal ini perlu dikaji sejauh mana akses dan pelayanan yang mereka dapatkan dengan adanya UUBH ini, serta hambatan-hambatan apa saja yang ada dalam proses implementasinya.

Penelitian ini bertujuan: Pertama, untuk mengetahui dan menganalisis implementasi pemberian bantuan hukum bagi rakyat miskin di Jawa Tengah berdasarkan UUBH; Kedua, untuk mengetahui hambatan-hambatan dalam implementasi UUBH. Secara teoritik, penelitian ini menjadi sumbangan referensi bagi kalangan akademisi yang ingin memperdalam pengetahuan mengenai implementasi pemberian bantuan hukum bagi rakyat miskin di Jawa Tengah. Sedangan sisi praktis, kegunaan penelitian ini yaitu: (1) Sebagai sarana sosialisasi kepada masyarakat mengenai adanya pemberian bantuk hukum; (2) Meningkatkan kinerja bagi pemberi bantuan hukum untuk memberikan bantuan hukum dengan penuh tanggung jawab sebagai bentuk pelayanan pada masyarakat; (3) menjadi sumbangan pemikiran bagi Pemerintah Republik Indonesia guna melakukan revisi yang diperlukan terhadap peraturan perundang-undangan, sehingga dapat lebih mengakomodir kepentingan hukum masyarakat miskin

\section{Rumusan Masalah}

Berdasarkan latar belakang masalah di atas, penulis rumuskan permasalahan sebagai berikut: Pertama, apakah implementasi pemberian bantuan hukum bagi rakyat miskin di Jawa Tengah sudah sesuai dengan Undang-Undang Nomor 16 Tahun 2011 tentang Bantuan Hukum; Kedua, apa hambatan dalam implementasi pemberian bantuan hukum bagi rakyat miskin di Jawa Tengah tersebut. 


\section{Metode Penelititan}

Penelitian ini merupakan penelitian kualitatif dengan metode pendekatan normatif-empiris. Data yang digunakan adalah data primer dan sekunder yang berasal dari hasil studi pustaka, survei, observasi, wawancara. Sumber data utama berasal dari kata-kata, tindakan dan selebihnya adalah dokumen dan lain-lain. Penelitian dilakukan di Jawa Tengah. Sasaran dari penelitian ini adalah norma hukum dan perilaku masyarakat. Informan dalam penelitian ini ditentukan secara purposive, yaitu Badan Pembinaan Hukum Nasional (BPHN), Kantor Wilayah Hukum dan Hak Asasi Manusia Jawa Tengah (Kanwilkumham), Lembaga Bantuan Hukum (LBH), dan rakyat miskin yang bermasalah dengan hukum. Informan dalam penelitian ini tidak terbatas pada jumlah tertentu, karena dalam penelitian ini menggunakan prinsip snowball yang dapat terus berkembang. Metode analisis yang dipergunakan adalah metode kualitatif yang menghasilkan data deskriptif-analitis.

\section{Pembahasan}

\section{Wewenang implementasi bantuan hukum}

Undang-Undang No. 16 Tahun 2011 tentang Bantuan Hukum (UUBH) telah disahkan 4 Oktober 2011 dan baru efektif berlaku sejak Juli 2013. Pemberian layanan bantuan hukum pada UUBH tidak dilakukan langsung oleh pemerintah. Bantuan hukum tersebut dilaksanakan oleh LBH atau Organisasi Kemasyarakatan.

Pasal 2 UUBH mengatur bahwa pemberian bantuan hukum kepada penerima bantuan hukum diselenggarakan oleh menteri dan dilaksanakan oleh pemberi bantuan hukum berdasarkan undang-undang ini. Menteri yang dimaksudkan dalam hal ini adalah Menteri Hukum dan Hak Asasi Manusia. Hal tersebut selaras dengan yang disampaikan oleh Jawardi ${ }^{4}$, yang menjelaskan:

...Memang bantuan hukum ini sudah dijalankan sebelumnya melalui MA. Negara ingin memberikan jaminan yang lebih nyata, dan menyatukan pemberian

4 Jawardi, Kabid. Pemberdayaan Hukum Pusat Penyuluhan Hukum BPHN.

5 Hasil wawawancara dengan Jawardi, dilaksanakan pada 26 September 2014. dana bantuan hukum menjadi satu pintu, yakni melalui Kementrian Hukum dan Hak Asasi Manusia. Dengan perdebatan pasal demi pasal keluarlah UU BH ini. ${ }^{5}$

Dana bantuan hukum yang semula berada dibeberapa lembaga pemerintahan disatukan dalam satu pengelolaan dibawah Kemenkumham. Peran Kemenkumham di dalam program bantuan hukum ini secara garis besar mencakup 3 (tiga) aspek, yakni: (a) Membuat aturan teknis bantuan hukum; (b) Pengelola penyaluran dana bantuan hukum, dan (c) Pengawasan dan evaluasi pelaksanaan pemberian bantuan hukum.

Nungung Wahyu Triono ${ }^{6}$ mengatakan:

Dulu bantuan hukum menyebar diberbagai instansi, untuk efisiensi dan efektifitas menjadikan bantuan hukum menjadi satu pintu melalui Kementrian Hukum dan HAM". ${ }^{7}$ Apabila tujuan dipusatkannya dana bantuan hukum dalam satu pintu ini untuk efisiensi dan efektifitas, masih menjadi sebuah pertanyaan apakah dapat terwujud tujuan tersebut apabila peran yang dimiliki BPHN begitu besar.

Selama proses penelitian dilaksanakan, terlihat bahwa masih ada koordinasi yang kurang efektif didalam internal Kemenkumham. Pelaksanaan program bantuan hukum terlalu dipusatkan di Badan Pembinaan Hukum Nasional (BPHN). BPHN melakukan verifikasi dan akreditasi, meyalurkan dana bantuan hukum serta melakukan pengasawas dan evaluasi terhadap Lembaga Bantuan Hukum/OK. Kewenangan yang terlalu luas dalam satu instansi tidak akan berjalan efektif dalam pelaksanaannya, justru akan membuka peluang adanya penyalahgunaan wewenang.

\section{Pengawasan dan evaluasi}

PP No. 42 Tahun 2013 tentang Syarat dan Tata Cara Pemberian Bantuan Hukum dan Penyaluran Dana Bantuan Hukum mengatur mengenai ruang lingkup tugas dan wewenang dari unit kerja pengawasan dan evaluasi. Secara

6 Nunung Wahyu Triono, Kasubid. Penyuluhan Hukum Kanwilkumham Jawa Tengah, Perwakilan Kanwilkumham.

7 Hasil wawawancara dengan Nunung Wahyu Triono, dilaksanakan pada 26 September 2014. 
umum tugasnya sebagai berikut: (a) melakukan pengawasan atas pemberian Bantuan Hukum dan penyaluran dana Bantuan Hukum; (b) menerima laporan dari masyarakat mengenai adanya dugaan penyimpangan pemberian Bantuan Hukum dan penyaluran dana Bantuan Hukum; (c) melakukan klarifikasi atas adanya dugaan penyimpangan pemberian Bantuan Hukum dan penyaluran dana Bantuan Hukum; (d) mengusulkan sanksi kepada Menteri atas terjadinya penyimpangan pemberian Bantuan Hukum dan/ atau penyaluran dana Bantuan Hukum; dan (e)membuat laporan pelaksanaan pengawasan.

Selama penelitian berlangsung, ditemukan praktik pungutan yang dilakukan advokat terhadap penerima bantuan hukum di Solo. Sri Wahyuni mengatakan: "ada biaya yang dikeluarkan, katanya untuk biaya transportasi dan administrasi sebesar Rp 400.000,-“". Integritas seorang advokat yang melakukan pungutan semacam ini sangat dipertanyakan.

Hasil penelitian yang dilakukan menggambarkan pengawas pada praktiknya masih pasif. Pengawasan masih terpaku pada tataran adminstasi, belum pada aspek kualitas pemberian banuan hukum yang diberikan. Nunung menjelaskan:

Kalo ada yang demikian (pungutan kepada penerima bantuan hukum) laporkan ke kanwil, kami ada pengawas yang terdiri dari orang kanwil dan ada juga dari unsur pemerintah daerah. Laporan dengan menunjukan bukti identitas klien. Kita akan melindungi klien, nanti akan ditelusuri kasus tersebut. selama ini memang belum ada laporan. ${ }^{9}$

Melihat hal tersebut di atas, pengawasan seharusnya lebih aktif, jangan hanya menunggu laporan dari korban karena posisi korban sendiri tidak sadar bahwa dirinya sebagai korban.

\section{Kesiapan Lembaga Bantuan Hukum atau Or- ganisasi Kemasyarakatan dalam Pemberian Bantuan Hukum}

Secara umum LBH yang berada di Jawa Tengah secara administrasi sudah siap untuk memberikan bantuan hukum, ini dikarenakan mereka sudah berdiri jauh sebelum UUBH ada. Direktur Lembaga Bantuan Hukum Mawar Saron Semarang, Guntur Perdamaian mengatakan:

LBH ini sudah berdiri dahulu sebelum UUBH jadi tidak ada masalah dalam akreditasinya. Hanya pada saat prosesnya disuruh memberikan data perkara yang sudah ditangani, data yang menunjukan LBH ini berbadan hukum. Jadi dengan adanya UU ini kita hanya menyesuaikan dengan aturan yang ada saja... ${ }^{10}$

Penyesuaian LBH terhadap UUBH banyak dilakukan oleh LBH yang mempunyai komitmen tinggi dan memang bersungguh-sungguh untuk memberikan bantuan hukum. LBH yang berdiri jauh sebelum UUBH ini lahir akreditasinya $A$ dan B, seperti: LPKBHI IAIN Walisongo, LBH Perisai Kebenaran, dan LBH Mawar Sharon Semarang. Bagi LBH yang baru berdiri setelah UUBH ini rata-rata mereka terakreditasi C seperti: LBH Miftakhul Jannah, LKBH STAIN Purwokerto, LBH Mega Bintang dan LBH lain seperti dalam lampiran skripsi ini.

LBH yang terkategori $\mathrm{C}$ tidak banyak melakukan perubahan menyesuaikan dengan UUBH. Dijumpai beberapa temuan terkait dengan ini, antara lain: (1) Sekretariat yang kosong pada saat jam pelayanan; (2) Sekretariat kurang memadai; (3) Buku adminitrasi yang kurang layak; (4) Sarana dan prasarana yang tidak mendukung; dan (5) Papan kesekretariatan tidak ada.
8 Hasil Wawancara dengan Sri Wahyuni, Penerima Bantuan Hukum di Solo, dilaksanakan pada 4 September 2014.

9 Hasil wawawancara dengan Nunung Wahyu Triono, dilaksanakan pada 26 September 2014.
10 Hasil wawawancara dengan Guntur Perdamaian, Direktur LBH Mawar Sharon Semarang, dilaksanakan pada 26 September 2014. 
Gambar 4: LKBH STAIN Purwokerto Tutup di jam pelayana

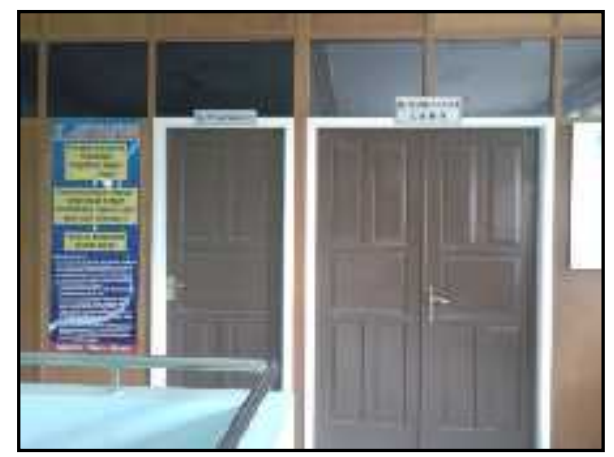

\section{Verifikasi dan Akreditasi Lembaga Bantuan Hukum}

Pasal 1 angka 1 Permen No. 3 Tahun 2013 tentang Verifikasi dan Akreditasi menyebutkan, bahwa Verifikasi adalah pemeriksaan atas kebenaran laporan dan dokumen yang diserahkan oleh Lembaga/organisasi bantuan hukum kemasyarakatan.

Pelaksanaan verifikasi lembaga bantuan hukum banyak dibantu oleh lembaga donor asing. Hal ini disampaikan Yulia sebagai berikut:

Perlu diketahui, soal pendanaan dalam pelaksanaan verifikasi, Panitia Verifikasi dibantu oleh mitra pembangunan yaitu organisasi-organisasi internasional seperti United Nations Development Programme (UNDP), Yayasan Tifa, dan AusAid melalui program Australia Indonesia Partnership for Justice (AIPJ). ${ }^{11}$

Proses pelaksanaan verifikasi dibagi menjadi 2 (dua), yaitu verifikasi administrasi dan veryfikasi faktual (lapangan). Proses verifikasi administrasi diikuti oleh 593 LBH. Jawardi menjelaskan:

Ada 593 OBH mendaftar. Setelah dilaksanakan verifikasi administrasi dan faktual di lapangan, lulus $310 \mathrm{LBH}$. Dari yang lulus itu terdapat $\mathrm{LBH}$ yang belum ber-BH. Yang belum ber $\mathrm{BH}$ diluluskan dulu sesuai intruksi menteri, dan diberi kelonggaran waktu selama 2 bulan untuk menjadi ber$\mathrm{BH}$. Namun banyaknya berkas, dalam masa 2 bulan tersebut ada LBH yang

11 Hasil wawawancara dengan Yulia Wiranti, dilaksanakan pada 26 September 2014.

12 Hasil wawawancara dengan Jawardi, dilaksanakan pada 26 September 2014. mampu mengurus, sehingga hanya ada 270 fiks dan tercatat sebagai pemberi bantuan hukum. ${ }^{12}$

Ada semacam kecenderungan di-sini, dimana upaya jemput bola yang dila-kukan oleh BPHN dan Kanwilkumham da-lam proses verifikasi LBH tahap pertama hanya ditujukan kepada LBH yang mereka ketahui, selain itu juga karena terbatas pada anggaran yang ada. Sehingga timbul bentuk ketidakadilan dalam proses pelak-sanaan verifikasi ini. Hal ini diakui oleh Yulia yang mengatakan:

Kita akui kalau saat ini LBH yang terakreditasi memang belum merata di Indonesia, dominasi masih berada di Jawa. Masih ada provinsi yang belum terdapat LBH yang terakreditasi disana. Namun demikian, kita terus berupaya untuk mendorong supaya mereka mengakreditasi LBH-nya. ${ }^{13}$

\section{Permasalahan Surat Keterangan Tidak Mam- pu (SKTM)}

Bagi calon penerima bantuan hukum, SKTM menjadi sesuatu yang mutlak harus dimiliki untuk menunjukan bahwa dirinya merupakan orang miskin dan layak untuk mendapat bantuan hukum. Asumsi bahwa pemilik SKTM pasti orang miskin juga kurang tepat. Hadaud Sumarno, menyampaikan:

Kriteria miskin cukup dibuktikan dengan adanya SKTM. Walau bisa disalahgunakan. Namun, jika sudah ada SKTM ya berarti orang tersebut berhak mendapat bantuan hukum cuma-cuma. Sebenarnya SKTM ini kurang efektif, sebab dapat dimanipulasi. Tapi kami suka tidak suka harus percaya... ${ }^{14}$

Yulia mengatakan: "miskin yang ada dalam UUBH memang masih debatable. Batasan khusus miskinnya juga tidak jelas, apakah miskin karena tidak mampu secara ekonomi, atau miskin pengetahuan tentang hukum ini juga be-

13 Hasil wawawancara dengan Yulia Wiranti, dilaksanakan pada 26 September 2014

14 Hasil wawawancara bersama Hadaud Sumarno, dilaksanakan pada 27 Novermber 2014. 
lum jelas."15 Arif Sahudi berpendapat: "Salah satu kendala pada persepsi mengenai SKTM yang berbeda-beda, ini sering menjadi masalah sebagai penghambat proses reimbursement". ${ }^{16}$

Permasalahan mengenai SKTM ini tidak boleh berlarut-larut, perlu ada penyelesaian yang jelas. Apabila ini terus berlanjut, proses pemberian bantuan hukum akan terhambat.

\section{Minimnya Anggaran Bantuan Hukum}

Menurut LBH yang menjadi Informan, anggaran dana bantuan hukum yang kurang mencukupi menjadi suatu permasalahan, Satu LBH untuk perkara litigasi senilai adalah $R p$ 5.000.000,- (lima juta rupiah). Bahrul Ulum mengatakan:

5 juta Sebenarnya tidak cukup, apalagi perkara pidana dan dimulai dari kepolisian. Waktunya lama, banyak yang dikeluarkan. Perdata juga agak berat, pendaftaran perkara dibayarkan oleh kita. Siasatnya kita dengan meminta keringanan kepada advokat, untuk dikurangi biayanya. ${ }^{17}$

Hal serupa juga disampaikan oleh Slamet Haryanto:

Logikanya 5 juta tidak cukup. Misal perkara perdata, perceraian biayanya 600 . Untuk biaya kesana kemari sudah banyak. Apalagi di PN negeri biaya 1,5 juta minimal, Jarak tempuh beracara disana nilai 5 juta tidak cukup. ${ }^{18}$

Dana menjadi aspek penting dalam pemberian bantuan hukum ini. Apabila pemerintah serius, seruan seperti ini patut menjadi perhatian pem-erintah. Dana bantuan hukum tidak hanya untuk pelayanan perkara, namun juga untuk sarana dan prasarana $\mathrm{LBH}$.

\section{Pro-Kontra Mekanisme Reimbursement}

Yulia Wiranti menjelaskan mengenai reimbursement. Menurutnya "reimbursement sa-

15 Hasil wawawancara dengan Yulia Wiranti, dilaksanakan pada 26 September 2014

16 Hasil wawawancara dengan Arif Sahudi, dilaksanakan pada 2 September 2014.

17 Hasil wawawancara dengan Bahrul 'Ulum, dilaksanakan pada 11 Desember 2014.

18 Hasil wawawancara dengan Slamet Haryanto, dilaksanakan pada 1 Desember 2014. ma dengan klaim. Sistem pembayaran yang pada prinsipnya mereka (LBH) membela orang miskin dulu, mereka wajib mendokumentasikan kegiatan, baru kita cairkan biayanya". ${ }^{19}$ la menambahkan:

Sistem reimbursement sudah disepakati bersama pada saat seluruh LBH dikumpulkan. Saat itu Menkeu mengatakan "boleh kalau anda tidak mau reimbursement (dengan uang muka) tapi LBH harus punya bank garansi. LBH punya jaminan kepada kita sejumlah uang yang didapat." Hal ini dilakukan karena dikhawatirnya sudah dikasih duit nanti kabur, sudah sampai di pengadilan tiba-tiba perkara ditinggalkan. Ini akan lebih rawan masalah kedepannya. ${ }^{20}$

Slamet Haryanto menyatakan: "proses reimbursement ini kurang tepat. Lebih baik dengan model LBH diberi modal dulu, akhir tahun membuat laporan dan melakukan pengembalian kelebihan dana, sehingga tidak ada keterlambatan pencairan dana". ${ }^{21}$ Pendapat berbeda disampaikan oleh Bahrul U'lum, ia mengatakan: "Model reimbursement sebenarnya bagus, LBH dituntut supaya melaksanakan kewajiban dulu baru menuntut haknya, tapi sayang dalam praktek masih tidak transparan dan tidak jelas". ${ }^{22}$

Pro-kontra terhadap kebijakan memang wajar. Namun kedepan aspek-aspek teknis dilapangan perlu diperhatikan. Awalnya memang sudah disepakati bersama model reimbursement ini. Perlu ada perubahan untuk mencari solusi terbaik supaya proses pemberian bantuan hukum berjalan dengan lancar.

\section{Dana Tidak Transparan Dan Turun Tidak Se- suai Harapan}

Keluhan mengenai dana yang turun tidak sesuai dengan yang dirasakan oleh semua LBH yang menjadi obyek penelitian. Slamet mengatakan:

19 Hasil wawawancara dengan Yulia Wiranti, dilaksanakan pada 26 September 2014

20 Hasil wawawancara dengan Yulia Wiranti, dilaksanakan pada 26 September 2014

21 Hasil wawawancara dengan Slamet Haryanto, dilaksanakan pada 1 Desember 2014.

22 Hasil wawawancara dengan Bahrul 'Ulim, dilaksanakan pada 12 Desember 2014. 
...Cairnya dana menjadi pengalaman teman-teman LBH semua, karena tidak sesuai dengan yang diharapkan. Contoh: mengajukan 13 kasus, apabila kasus belum inkrah, tahap awal diberikan 2 juta. Kalau sudah putus diberikan 3 juta berikutnya. Pengalaman kita semua, kita ngirim 13 kasus, 2 sudah inkrah. 11 kasus belum inkrah. Harusnya keluar 32 juta, namun yang keluar hanya 14 juta. Sebuah evaluasi. Ini menjadi kendala dalam proses proses pemberkasan, mungkin tidak sesuai dengan pemeriksa misal BPK atau apa, seharusnya dikembalikan. ${ }^{23}$

Persoalan demikian perlu menjadi catatan khusus bagi BPHN yang sampai saat ini masih memegang proses pencairan dana. Proses pencairan dana harus dilaksanakan secara jelas dan transparan. Dari permohonan yang diajukan oleh LBH yang dicairkan kegiatan yang mana harus jelas, supaya LBH tidak menilai negatif terhadap proses penyelenggaraan ini. Hal ini tentunya tidak sesuai dengan asas keterbukaan yang terdapat dalam UUBH.

\section{Akses dan Pelayanan Bantuan Hukum Minimnya Informasi Bantuan Hukum}

Secara umum dapat digambarkan bahwa masih banyak rakyat miskin yang tidak tahu program pemberian bantuan hukum yang diselenggarakan oleh pemerintah. Total ada 7 (tujuh) informan rakyat miskin, 5 (lima) diantaranya adalah Penerima bantuan hukum. Dari 5 (lima) yang menerima bantuan hukum, hanya ada 1 (satu) orang yang memang sudah tahu ada program bantuan hukum bagi rakyat miskin. Sutari ${ }^{24}$ menyampaikan: "Saya tidak tahu ada program bantuan hukum, saya juga baru pernah yang namanya datang ke pengadilan. Kalau tidak terpaksa saya juga tidak kesana". ${ }^{25}$ Pernyatan yang sama juga disampaikan oleh Boma Endarto ${ }^{26}$, Sri Wayuni ${ }^{27}$ dan Hastuti. ${ }^{28}$ Keempat pe-

23 Hasil wawawancara dengan Slamet Haryanto, dilaksanakan pada 1 Desember 2014.

24 Sutari, Penerima bantuan hukum perkara perdata di Purwokerto.

25 Hasil wawancara dengan Sutari, dilaksanakan pada 12 Desember 2014.

26 Boma Endarto, Penerima bantuan hukum perkara pidana di Semarang nerima bantuan hukum diatas juga awalnya tidak tahu apa itu bantuan hukum.

Fakta-fakta tersebut menunjukan sosialisasi yang menjadi tugas utama bagi BPHN, Kanwilkumham, dan Pemberi Bantuan hukum sebagai pelaksana lapangan masih kurang maksimal. Yulia menanggapi pernyataan mengenai mayoritas masyarakat miskin tidak tahu adanya bantuan hukum. la memeberi tanggapan sebagai berikut:

Ini dilematis, artinya bahwa saat ini memang masih banyak masyarakat yang belum tahu adanya UUBH ini. Kita sudah sosialisasi, namun kita terbatas anggaran. Apa daya kemampuan RAKL DIPA kita tidak mampu untuk melakukannya. Kita hanya sosialisasi di pusat provinsi, dan tidak ke semua provinsi kita datangi. Seluruh LBH wajib melakukan sosalisasi, termasuk dalam bantuan hukum nonlitigasi.... ${ }^{29}$

Menarik pernyataan dari BPHN dan Kanwilkumham yang sama-sama menyampaikan bahwa LBH adalah pihak yang paling memungkinkan untuk memberikan sosialiasi yang lebih luas dan merata. LBH dapat memasukan sosialisasi kedalam program nonlitigasi yang kemudian dapat melakukan reiumbursement atas pelaksanaan kegiatan yang telah dilaksanakan. Masalah baru muncul saat LBH kesulitan melakukan reimbursement dana bantuan hukum dari program nonlitigasi yang merasa administrasinya ribet.

\section{Jangkauan Pemberian Bantuan Hukum Masih Sempit}

Secara umum jangkauan pemberian bantuan hukum terkendala oleh faktor ketidakmerataan sebaran pemberi bantuan hukum itu sendiri dan keterbatasan dana bantuan hukum sebagaimana telah dijelaskan juga sebelumnya. $\mathrm{Di}$ Jawa Tengah, sebaran lokasi LBH yang menda-

27 Sri Wahyuni, Penerima bantuan hukum perkara perdata di Solo.

28 Hastuti, Penerima bantuan hukum perkara pidana di Solo.

29 Hasil wawawancara dengan Yulia Wiranti, dilaksanakan pada 26 September 2014 
patkan dana dari pemerintah untuk memberikan bantuan hukum bagi rakyat miskin belum merata, ini sebagaimana yang disampaikan oleh Nunung Wahyu Triono. Nunung mengatakan: "Persebaran memang belum merata. Di daerah sepanjang pantura belum ada, mulai dari Tegal sampai Batang." 30

Berdasarkan data yang diperoleh sebaran LBH yang memberikan bantuan hukum cumacuma tidak merata. Ini bisa dilihat pada lampiran artikel ilmiah ini. Perlu ada upaya pro aktif dari Kanwilkumham atau BPHN untuk mendorong pemerataan sebaran LBH yang memberikan layanan bantuan hukum secara cuma-cuma.

\section{Kualitas Pelayanan Pemberian Bantuan Hu- kum}

Menurut informasi yang didapatkan, ratarata dari mereka menerima bantuan hukum saat perkara sudah di pengadilan untuk pidana dan saat tahap gugatan untuk perkara perdata. Boma Endarto menyampaikan: "saya pertama didampingi pengacara mulai pertama sidang. Waktu itu bapak saya ditawari sama orang Peradi, namanya pak Nugroho. Katanya mau tidak diberi bantuan hukum, gratis tanpa biaya apapun. Kenyataannya memang kami tidak bayar sama sekali". ${ }^{31}$ Hal serupa juga disampaikan oleh Hastuti ${ }^{32}$ dan Sri Wahyuni. ${ }^{33}$

Banyak terjadi pelanggaran pada saat proses pemeriksaan di kepolisian. Pemeriksaan menekankan pada pengakuan tersangka, padahal jelas ini menyalahi asas praduga tak bersalah yang seharusnya tersangka mendapat perlakuan yang lebih manusiawi. Ini yang dirasakan oleh Boma Endarto, ia mengatakan: "Saya mendapat perlakuan yang sangat kasar waktu diperiksa oleh polisi. Muka saya dipukul, ditampar. Rasanya bener-bener kaya mau mati saat itu. Setelah itu saya tidak ingat apa-apa karena saya pingsan. Saya disuruh ngaku kalo yang ngambil motor itu saya, padahal saya tidak tahu

30 Hasil wawawancara dengan Nunung Wahyu Triono, dilaksanakan pada 26 September 2014.

31 Hasil wawancara dengan Boma Endarto, dilaksanakan pada 20 Januari 2015.

32 Hasil wawancara dengan hastuti, dilaksanakan pada 2 September 2014.

33 Hasil wawancara dengan Sutari, dilaksanakan pada 12 Desember 2014. apa-apa". ${ }^{34}$ Dugaan tersebut semakin kuat karena ada satu informan lagi yang menyatakan hal sama, dan kebetulan sama-sama diperiksa di Polres Semarang, yakni Subekhan, ${ }^{35}$ Subekhan menjelaskan sebagai berikut:

Saya dipukuli pakai rotan, ditampar, diinjak kakinya pakai sepatu. Selama beberapa jam saya diperlakukan seperti itu, sambil disuruh mengaku kalo saya yang melakukan pencurian. Padahal saya tidak tau apa-apa mas. Karena saya tidak tahan yaudah akhirnya saya bilang kalo yang nyuri itu saya, padahal saya juga tidak tau apa-apa. Setelah ngaku saya suruh tanda tangan dikertas. ${ }^{36}$

Kedudukan polisi yang lebih kuat menguntungkan dirinya atas posisi lemah tersangka yang tidak mengerti tentang hak-haknya ketika proses pemeriksaan berlangsung. Kasus-kasus diatas menjadi cerminan, bahwa perlindungan hukum terhadap rakyat miskin yang berhadapan dengan hukum kurang maksimal dan merata. Adanya hal demikian menunjukan bahwa polisi tidak paham, bahkan mungkin tidak tahu sama sekali mengenai adanya bantuan hukum. Seharusnya sejak awal polisi juga turut aktif minimal memberikan informasi adanya bantuan hukum. Terlihat ego sektoral masih melekat pada institusi ini.

\section{Adanya Pembatasan Pelayanan Bantuan Hukum}

Menolak perkara pada prinsipnya tidak boleh dilakukan oleh seorang advokat, namun apabila perkara yang dimohonkan untuk dibantu bertentangan dengan hati nurani, advokat dapat menolak dengan alasan yang logis. Hal ini juga yang dilakukan oleh LBH. Pada bagian ini, alasan pembatasan dikelompokan menjadi 2 (dua), yaitu karena keterbatasan biaya dan berseberangan dengan visi misi lembaga.

Pembatasan dengan alasan keterbatasan biaya ini sebagaimana yang dialami oleh LBH

34 Hasil wawancara dengan Boma Endarto, dilaksanakan pada 20 Januari 2015.

35 Subekhan adalah anak Solikhun yang dituduh melakukan pencurian.

36 Hasil wawancara dengan Subekhan, dilaksanakan pada 20 Januari 2015. 
STAIN Purwokerto, Bahrul Ulum menyampaikan: "Yang dibantu untuk litigasi sejumlah dengan perkara yang dibayarkan oleh BPHN. Kalau lebih kita sarankan untuk nunggu, kalau tidak mau nunggu kita sarankan ke LBH yang lain". ${ }^{37}$ Pernyataan serupa diampaikan oleh Slamet Haryanto, slamet mengatakan: "Pemberian bantuan hukum kita batasi jumlahnya sesuai dengan anggaran yang ada". ${ }^{38}$

Pembatasan dengan alasan bertentangan dengan visi misi lembaga ini disampaikan oleh Munir:

Kami fokus pada kasus stuktural, seperti buruh yang di PHK, pedagang kaki lima yang digusur, pencemaran lingkungan dll. Kasus yang ditolak yaitu yang berkaitan dengan kasus personal seperti perceraian, narkotika, korupsi, dll... ${ }^{39}$

\section{Hambatan Implementasi Pemberian Bantuan Hukum Bagi Rakyat Miskin di Jawa Tengah}

Faktor-faktor penghambat dalam implementasi pemberian bantuan hukum bagi rakyat miskin di Jawa Tengah, jika dikaji dari teori sistem hukum Lawrence M Friedman dan faktorfaktor yang mempengaruhi penegakan hukum dari soerjono soekatno dengan mengacu pada hasil penelitian, dapat diklasifikasikan menjadi 3 faktor yakni: faktor substansi hukum (legal substance), Struktur Hukum (legal Structure) dan budaya hukum (legal culture).

\section{Faktor Substansi Hukum (legal substance)}

Substansi hukum yakni peraturan perundang-undangan yang baik seharusnya disusun secara jelas dan tidak menimbulkan banyak penafsiran. Peraturan Perundang-undangan yang mengatur mengenai bantuan hukum masih mengandung kelemahan dan kekurangan-kekurangan. Hal ini tentu saja menghambat pelaksanaan bantuan hukum yang diberikan bagi orang atau kelompok orang miskin.

37 Hasil wawawancara dengan Bahrul 'Ulum, Direktur LKBH STAIN Purwokerto, dilaksanakan pada 11 Desember 2014.

38 Hasil wawawancara dengan Slamet Haryanto, Direktur PBH DPC PERADI Semarang, dilaksanakan pada 1 Desember 2014

\section{Persepsi Mengenai Miskin}

Pasal 1 angka 2 UUBH didalamnya disebutkan bahwa penerima bantuan hukum adalah orang atau sekelompok orang miskin. Ketentuan ini masih ambigu, miskin yang dimaksudkan itu yang seperti apa belum jelas, apakah miskin ilmu, miskin harta atau miksin yang lain.

Yulia mengatakan: "miskin yang ada dalam UUBH memang masih debatable. Batasan khusus miskinnya juga tidak jelas, apakah miskin karena tidak mampu secara ekonomi, atau miskin pengetahuan tentang hukum ini juga belum jelas". 40

Dua hal diatas dapat diketahui bahwa substansi hukum (legal substance) telah menjadi salah satu faktor penghambat yang mempengaruhi pelaksanaan bantuan hukum bagi rakyat miskin di Jawa Tengah. Kelemahan-kelemahan yang ada di dalam substansi peraturan perundang-perundangan yang mengatur mengenai bantuan hukum mempengaruhi pelaksanaan bantuan hukum, sehingga dalam prakteknya tidak terimplementasikan dengan baik.

\section{Persepsi Mengenai SKTM}

Syarat untuk menerima bantuan hukum salah satunya melampirkan Surat Keterangan Miskin dari lurah atau kepala desa sebagaimana yang terkadung dalam Pasal 14 ayat (1) huruf $c$ UUBH. Praktik dilapangan, yang dibuat desa atau kelurahan adalah Surat Keterangan Tidak Mampu. Nunung mengungkapkan: "Ada perbedaan penafsiran mengenai SKTM ini. Ada desa yang mengeluarkan Surat Keterangan Miskin dan ada yang mengeluarkan Suarat Keterangan Tidak Mampu. Namun sesuai dengan amanat UU, yang kami terima adalah Surat Keterangan Miskin. ${ }^{41}$

Perbedaan persepsi semacam ini akan menyulitkan baik calon penerima bantuan hukum itu sendiri, pemberi bantuan hukum dan aparat perintah desa atau kelurahan. Jangan sampai

39 Hasil Wawawancara dengan Munir, Direktur LBH-YLBH Semarang, dilaksanakan pada 27 November 2014.

40 Hasil wawawancara dengan Yulia Wiranti, dilaksanakan pada 26 September 2014.

41 Hasil wawawancara dengan Nunung Wahyu Triono, dilaksanakan pada 26 September 2014. 
permasalah administrasi menghambat proses pemberian bantuan hukum.

\section{Struktur Hukum (legal structure)}

Faktor struktur hukum (legal structure) dalam pembahasan ini meliputi faktor penegak hukum dan sarana atau fasilitas. Pembahasan mengenai struktur hukum (legal structure) akan dibedakan menjadi 2 (dua) yaitu: Pertama, faktor internal. Faktor internal merupakan faktor yang berasal dari dalam diri. Berdasarkan hasil wawancara dan observasi dilapangan yang mempengaruhi penegakan hukum lebih pada faktor intergritas, moralitas, idealisme, dan profesionalisme. Kedua, faktor eksternal. Faktor eksternal adalah faktor dari luar penegak hukum, selain dari luar penegak hukum juga meliputi faktor sarana atau fasilitas. Hasi penelitian menunjukan bahwa yang mempengaruhi implementasi bantuan hukum dari faktor ini adalah anggaran dana bantuan hukum yang terbatas, serta sarana sekretariat yang kurang mendukung.

\section{Budaya Hukum (legal culture)}

Faktor budaya hukum (legal culture) dalam pembahasan ini meliputi faktor budaya hukum atau kebudayaan dan masyarakat.

\section{Faktor budaya hukum}

Kurangnya kesadaran moral, profesionalitas, integritas, kesadaran dan ketaatan hukum dalam memenuhi tugas dan kewajibannya sebagai advokat, sehingga menimbulkan penyimpangan-penyimpangan berupa penolakan memberikan bantuan hukum dan tindakan advokat yang tidak profesional dan diskriminatif dalam pelaksanaan bantuan hukum tentu menghambat pelaksanaan bantuan hukum.

\section{Faktor masyarakat}

Secara umum dapat diketahui bahwa faktor masyarakat yang mempengaruhi pelaksanaan pemberian bantuan hukum bagi rakyat miskin di Jawa Tengah adalah anggapan, opini, atau pandangan masyarakat yang negatif terhadap pemberian bantuan hukum.

\section{Penutup \\ Simpulan}

Implementasi bantuan hukum bagi rakyat miskin di Jawa Tengah belum terimplementasi dengan Hal ini dikarenakan beberapa faktor, antara lain: (1) Pengawasan belum maksimal; (2) Masih banyak orang miskin yang tidak tahu adanya program bantuan hukum; (3) Masih banyak orang miskin yang berperkara tidak mendapatkan bantuan hukum; (4) Proses reimbursement yang sering terlambat; (5) Ego sektoral lembaga hukum yang terkait masih tinggi; dan (6) Administrasi reimbursement yang terlalu ribet belum efektif dan efisien.

Faktor-faktor penghambat pelaksanaan bantuan hukum bagi rakyat miskin di Jawa Tengah ada 3 (tiga) faktor, yakni: (1) Faktor substansi hukum (legal substance); (2) Struktur hukum (legal structure); dan (3) Budaya hukum (legal culture).

\section{Saran}

Berkaitan dengan implementasi UUBH, saran dari penulis yakni: (1) Pemerintah dan LBH dituntut harus pro-aktif untuk terus mensosialisasikan UUBH; (2) Perlu pengingkatan koordinasi antar lembaga yang terkait terhadap pelaksanaan bantuan hukum; (3) Pengalihan wewenang pelaksanaan teknis BPHN ke kanwilkumham.

Berkaitan dengan hambatan-hambatan implementasi, ada beberapa hal yang dapat dilakukan, antara lain: (1) Faktor substansi hukum harus dikaji lebih lanjut, memberikan batasan yang jelas mengenai pengertian miskin dalam UUBH serta permasalahan mengenai tafsir SKTM, perlu ada pemberitahuan secara strukturan ke desa atau kelurahan yang mengeluarkan surat tersebut; (2) Adanya pendidikan hukum bagi pelaksana pemberian bantuan hukum dan masyarakat untuk meningkatkan pengetahuan filosofi bantuan hukum; (3) Meningkatkan pengawasan, baik ditingkat pusat maupun daerah; Menaikan anggaran dana bantuan hukum; Memberikan sosialisasi kepada masyarakat secara masif mengenai hak-hak hukum serta bantuan hukum. 


\section{Daftar Pustaka}

Bantuan Hukum dan Workshop Sosio Legal FH Universitas Brawijaya. 2013);

Soekanto, Soerjono. Bantuan Hukum: Suatu Tinjauan Sosio-Yuridis. (Jakarta: Ghalia Indonesia. 1983);

Sunggono, Bambang dan Harianto, Aries. 2009. Bantuan Hukum dan Hak Asasi Manusia. CV. Mandar Maju. Bandung;

Winarta, Hendra, Frans. Bantuan Hukum; Suatu Hak Asasi Manusia Bukan Belas Kasihan. (Jakarta: PT Elex Media Komputindo Kelompok Gramedia. 2000);

Bantuan Hukum di Indonesia (Hak untuk di Dampingi Penasehat Hukum bagi Semua Warga Negara. (Jakarta: PT. Elek Media Komputindo. 2011).

\section{Jurnal}

Taufik, Ade, Irawan. "Sinergitas Peran dan Tanggung Jawab Advokat dan Negara dalam Pemberian Bantuan Hukum CumaCuma". Jurnal Rechtsvinding. Vol. 2 No. 1 April 2013. Jakarta: BPHN;

Winarta, Frans, Hendra. dalam Muzzaqi. "Menggagas Bantuan Hukum Bagi Rakyat Miskin". Jurnal Konstitusi. Vol 6. No. 3. Tahun 2009. Jakarta: Mahkamah Konstitusi;

Setiyawan, Iwan \& Nasution, Adawiyah. "Proses Pemberian Bantuan Hukum Secara Prodeo Terhadap Pelaku Tindak Pidana oleh Advokat". Jurnal Kultura. Vol. 15 No. 1 September 2014. Medan: Universitas Muslim Nusantara AI-Washliyah.

\section{Peraturan Perundang-undangan}

Undang-Undang Dasar Negara Republik Indonesia Tahun 1945

Undang-Undang Nomor 16 Tahun 2011 tentang Bantuan Hukum;

Peraturan Pemerintah Nomor 42 Tahun 2013 tentang Syarat Dan Tata Cara Pemberian Bantuan Hukum Dan Penyaluran Dana Bantuan Hukum;

Peraturan Menteri Hukum dan Hak Asasi Manusia Nomor 3 Tahun 2013 tentang Syarat dan Tata Cara Pemberian Bantuan Hukum;
Peraturan Menteri Hukum dan Hak Asasi Manusia Nomor 22 Tahun 2013 tentang Tata Cara Verifikasi dan Akreditasi 